\title{
Ensuring the Required Potable Water Temperature in Water Pipeline Inside Buildings
}

\author{
Dominika Mackováa ${ }^{*}$, Jana Peráčková1 \\ 1 Department of Building Services, Faculty of Civil Engineering, Slovak University of Technology in Bratislava, 81005 Bratislava, \\ Radlinského 2766/11, Slovakia \\ * Corresponding author, e-mail: dominika.mackova@stuba.sk
}

Received: 16 March 2021, Accepted: 03 May 2021, Published online: 09 August 2021

\begin{abstract}
The paper deals with the requirements of the potable water cold temperature and water exchange in water piping system inside buildings. The contribution describes the main factors influencing the hygiene of potable water in terms of its temperature and a exchange in the pipeline. In buildings, the resulting water hygienic risks can be reduced using the right technical solution. The technical measures described in the paper are usage of the automatic water flushing system, design of the potable water cold circulation and cooling system and optimization of the water pipeline distribution system inside buildings.
\end{abstract}

Keywords

potable water, water stagnation, sanitary installation

\section{Introduction}

In addition to hygienic safety, the basic requirements of potable water quality also include its temperature. In buildings, we can observe a trend of reducing water consumption due to water saving by end users. These water savings can be associated with possible hygienic risks. Due to the lower potable water consumption, it is insufficiently exchanged water in the pipeline system, the water flows at a slower speed and limit values of the potable water temperature in the water supply are exceeded.

\section{Description of the current state}

Water exchange in a pipeline system is defined as the complete exchange of the volume of water contained in the relevant part of the pipeline by taking water or draining it. If the water supply system is designed to secure the sufficient water exchange in water pipes, then a suitable potable water temperature will also be ensured. Optimal potable water cold (referred as a PWC) temperature is important not only from the user's comfort point of view, but also from the possible risk of bacteria multiplying. According to BS EN 806-2 [1], after 30 seconds from opening the water tap, the temperature of cold water must not exceed $25{ }^{\circ} \mathrm{C}$. With a PWC temperature limit value of $25{ }^{\circ} \mathrm{C}$ agrees also the technical normalization information TNI CEN/TR 16355 [2], which stipulates that to prevent the colonization of bacteria Legionella, the water temperature must be in such a range that the bacterium does not multiply at all, i.e. the water temperature must be below $25^{\circ} \mathrm{C}$. Decree of the Ministry of Health of the Slovak Republic no. 247/2017 Coll. [3] On the quality of water intended for human consumption indicates the recommended range of the PWC temperature from 8 to $12{ }^{\circ} \mathrm{C}$. With today's available pipe insulation materials with good quality, ensuring the proper PWC temperature should be automatic.

The causes of high PWC temperatures inside buildings include:

- phases of water stagnation in the pipeline system,

- irregular water abstraction from water taps,

- insufficient insulation of cold-water pipes,

- high temperature of PWC in the water supply pipe at the entrance to the building.

\section{Stagnation of water in the pipeline system and its effect on the temperature of cold water}

During the distribution of PWC in the building, the water stagnates. Fig. 1 shows the course of PWC temperature in the experimental measurement [4], which shows on the direct dependence of the PWC temperature on its flow. When water is taken, its temperature is constant or is decreasing. However, if there is no water flow (water 


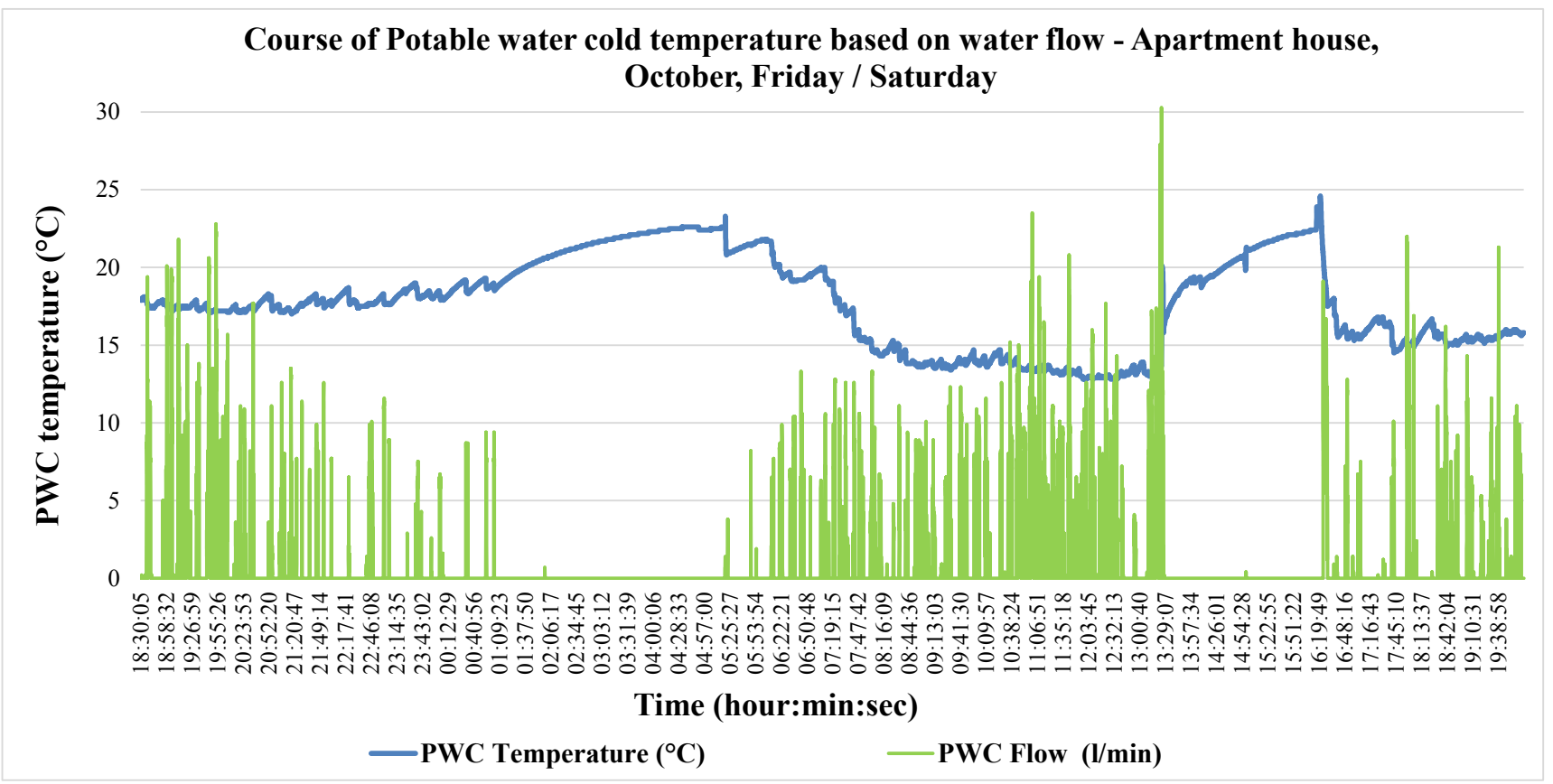

Fig. 1 Behavior of temperature and flow of potable water cold during experimental observation in apartment house, measurement performed for 1 riser pipe for 12 apartments, 30 inhabitants (graph prepared by the author on the basis of provided data from the source [4])

stagnates), the cold water is heated. The PWC temperature during this measurement was the most critical at the time from 13:30 to 16.30, when the temperature has increased because of water stagnation from 14 to $25^{\circ} \mathrm{C}$.

The temperature of cold water at the entrance to the building is very important. If the PWC temperature at the entrance to the building is $20^{\circ} \mathrm{C}$, the limit value of $25^{\circ} \mathrm{C}$ is exceeded very quickly. In the article there are described technical measures to ensure the required PWC temperature in water supply system inside buildings. The basic measure to avoid mutual heat transfer between cold water and hot water pipes or the ambient is the insulation of PWC pipe. Recommended minimum thicknesses of cold-water pipe thermal insulation layers are given in Table 1.

\section{Automatic water flushing units}

One of the possible technical measures to ensure the required potable water exchange and temperature in the pipe system is the design of automatic water flushing units. The water in the distribution system inside buildings should be changed at least once a week [1]. If it is not possible to change the water volume in the pipeline system manually, once a week, opening every release valve, it is possible to use an automatic flushing unit (Fig. 2). The unit flush the section of pipe based on the program set on the control unit.

The technology allows the flushing units to be configured based on three operating modes:
Table 1 Recommended minimum thicknesses of a thermal insulation layer of cold water pipes with $\lambda_{\text {insulation }}=0.040 \mathrm{~W} /(\mathrm{m} . \mathrm{K})$ [5]

\begin{tabular}{lc}
\hline Pipe laying & $\begin{array}{c}\text { Thicknesses of } \\
\text { insulation }\end{array}$ \\
\hline $\begin{array}{l}\text { Cold water pipes laid in unheated rooms, } \\
\text { ambient temperature } \leq 20^{\circ} \mathrm{C}\end{array}$ & $9 \mathrm{~mm}$ \\
$\begin{array}{l}\text { Cold water pipes in shafts, channels, suspended } \\
\text { ceilings, ambient temperature } \leq 25^{\circ} \mathrm{C}\end{array}$ & $13 \mathrm{~mm}$ \\
$\begin{array}{l}\text { Cold water pipes laid in v technical room, } \\
\text { shafts, channels, suspended ceilings, ambient } \\
\text { temperature }>25^{\circ} \mathrm{C}\end{array}$ & $\begin{array}{c}\text { Thickness is equal } \\
\text { to the pipe internal } \\
\text { diameter }\end{array}$ \\
$\begin{array}{l}\text { Cold water pipes laid in pre-wall installations } \\
\text { Cold water pipes in the floor, laid without hot }\end{array}$ & $\begin{array}{c}4 \text { mm or in a } \\
\text { protective tube }\end{array}$ \\
water pipes & mm or in a \\
$\begin{array}{l}\text { Cold water pipes in the floor, laid with hot } \\
\text { water pipes }\end{array}$ & \\
\hline
\end{tabular}

1. Operating mode by TIME

Setting example: Flush the pipe for 10 minutes every Monday at 6 am.

- Advantages: simple installation and programming

- Disadvantages: unnecessary water consumption if the water flushing is sufficient 


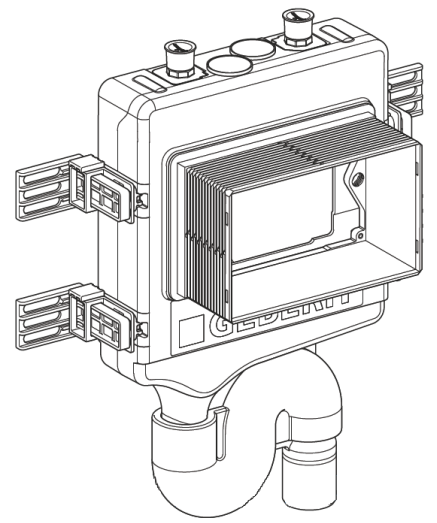

(a)

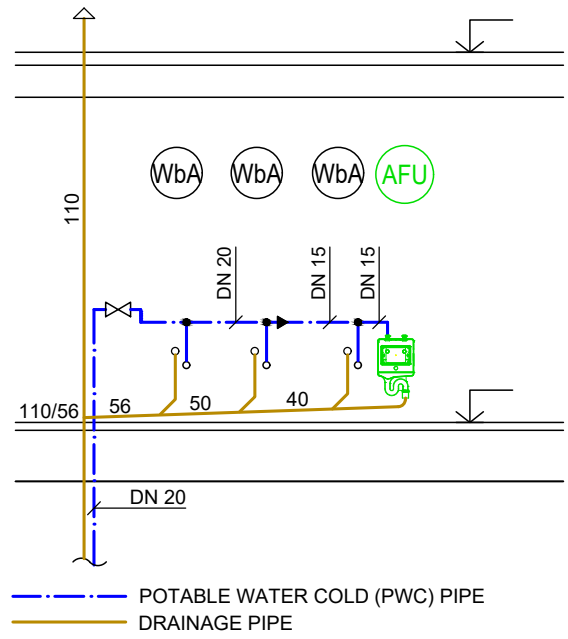

(b)

Fig. 2 Automatic water flushing unit; (a) view on flushing unit [6]; b) scheme of the location of the automatic flushing unit [author];

AFU - automatic flushing unit, $\mathrm{Wb}$ - Washbasin

\section{Operating mode by WATER FLOW}

Setting example: Flow the pipe section until the 50 liters of water flows through the pipe in last 24 hours.

- Advantages: reliable flow volume control

3. Operating mode by TEMPERATURE

Setting example: If the temperature in pipe section exceeds $25{ }^{\circ} \mathrm{C}$, flush the pipe section until the temperature drops below $20{ }^{\circ} \mathrm{C}$.

- Advantages: ensured the required PWC exchange and temperature, reliable control of temperature

\section{Potable water cold circulation (PWC-C) and cooling system}

In the case of an automatic water flushing unit, to ensure a sufficient water exchange, the water is discharged into the sewerage system and the valuable potable water is wasted. This disadvantage can be eliminated by designing a potable water cold circulation system (referred as PWC-C) with cooling of the potable water. In Fig. 3 is a schematic diagram of PWC-C in a building. The PWC circulates in a circulation line using a circulation pump and the required PWC temperature and exchange is maintained. The PWC circulation pipe is led to the technical room, where the cooling process takes place. The following technologies can be used to cool potable water cold:

1. compressor cooling (see Subsection 5.1):

- using an air conditioning unit,

- using a heat pump,

2. solar cooling (see Subsection 5.2),

3. existing cooling systems in the building can also be used for cooling cold water [7].

The design of a PWC-C system depends on:

1. PWC temperature at the entrance to the building,

2. desired PWC outlet temperature after cooling,

3. ambient temperatures around the cold water and circulation pipes,

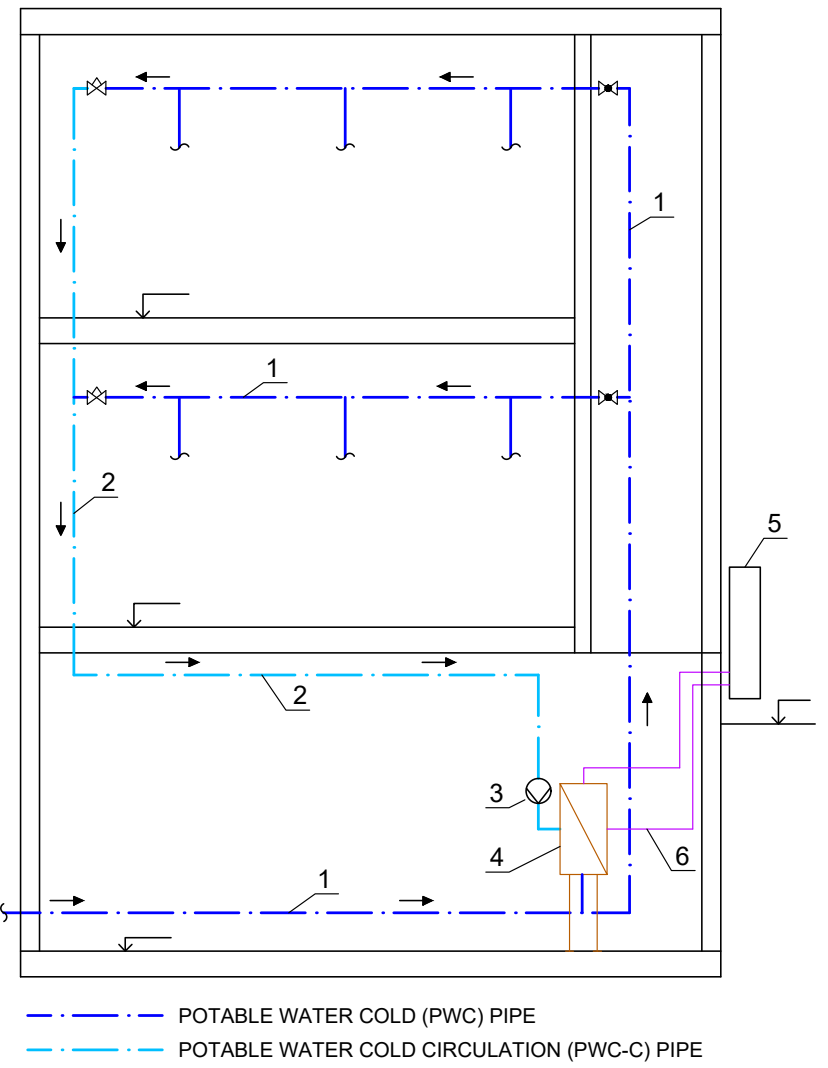

Fig. 3 Principle diagram of the potable water cold circulation with cooling using heat exchanger and air conditioning unit [author, 7]; 1 - PWC pipe, 2 - PWC-C pipe, 3 - circulation pump, 4 - exchanger, 5 - air conditioning unit, 6 - refrigerant 
4. pipe lengths,

5. pipe dimensions.

The system includes its hydraulic regulation and system measurement and regulation.

Inside buildings, a separate water supply system can be designed - a separate pipeline for the water supply for flushing toilets and a separate pipeline for the water supply to washbasins and sinks (Fig. 4). In this case, the PWC would circulate and be cooled only for the section of the water supply for washbasins and sinks, for the purpose of supplying fresh PWC for drinking and cooking purposes. A matter of course with the internal water pipeline is a separate fire extinguish water pipe to supply hydrants, which is separated from the potable water pipeline system with a protective unit to prevent pollution by water backflow.

\subsection{Compressor cooling of cold water}

Fig. 5 shows the principle of compressor PWC cooling using an outdoor air conditioning unit and an exchanger. PWC with undesired temperature is fed into the heat exchanger using a circulation pump. Refrigerant is fed to the exchanger, on the

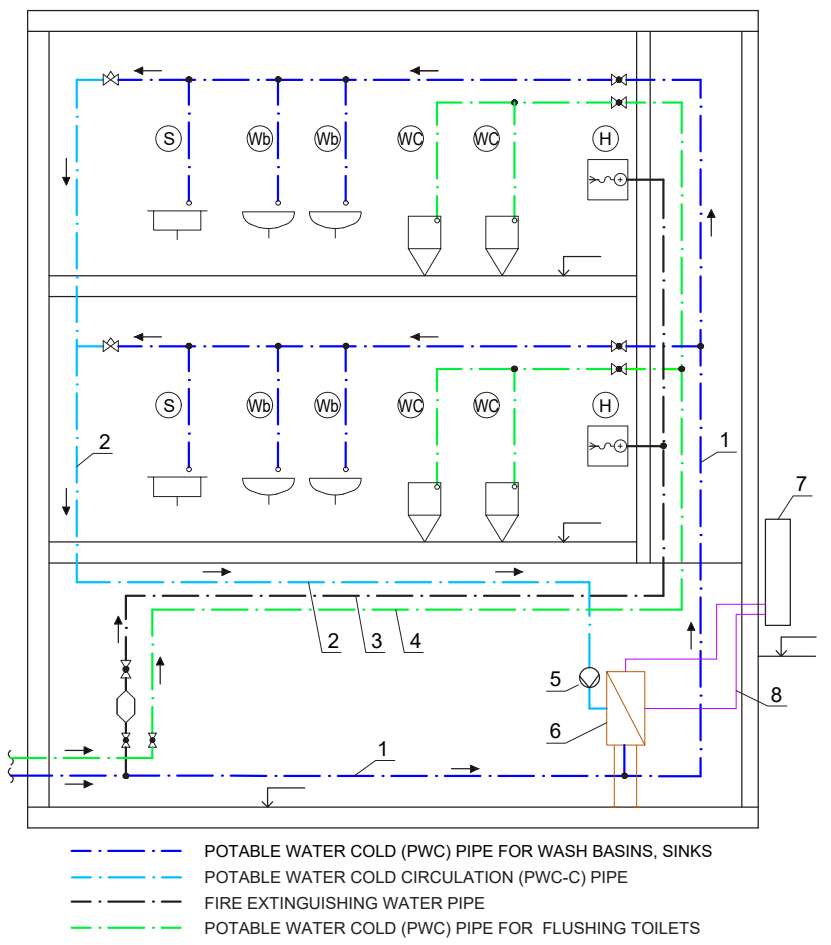

Fig. 4 Scheme of the potable water cold circulation in the case of separate water pipeline systems inside building (author); 1 - PWC pipe,

2 - PWC-C pipe, 3 - fire extinguish water pipe, 4 - PWC pipe for flushing toilets (rain water), 5- circulation pump, 6 - exchanger, 7 - air conditioning unit, 8 - refrigerant, $\mathrm{Wb}$ - washbasin, $\mathrm{WC}$ - toilet, $\mathrm{S}-\operatorname{sink}, \mathrm{H}-$ wall hydrant

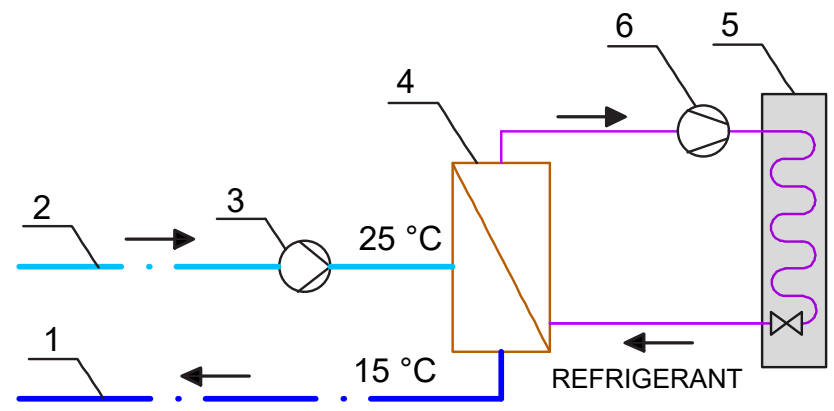

Fig. 5 Scheme of PWC compressor cooling with air conditioning unit and exchanger (author); 1 - cold water pipe, 2 - cold water circulation pipe, 3 - circulation pump, 4 - exchanger, 5 - outdoor air conditioning unit, 6 - compressor

opposite side. Between PWC and the refrigerant is running the heat energy exchange, the PWC is cooled and is distributed to the individual water consumption points. The refrigerant, which transfers its energy to PWC, heats up, raises its temperature, and changes state from liquid to gas. Through the compressor, the gas is compressed, its pressure and temperature increase, and in this condition is fed to an outdoor air conditioning unit. In the air conditioning unit, the refrigerant condenses and precipitates excess heat to the outside environment, reducing its temperature. The refrigerant pressure is reduced using an expansion valve. The refrigerant state is changed to liquid state and then fed to a heat exchanger, where it cools the cold water again. At the outlet of the exchanger, $\mathrm{PWC}$ can reach a temperature in the range of approximately 10 to $15^{\circ} \mathrm{C}$.

Several issues like corrosion, scale, fouling, and microbial growth will reduce flow rates and heat transfer rates and lower system efficiency. It is therefore very useful to install a filter before the circulation pump, to eliminate the capture of impure substances such as organic matter and suspended solids from water. Using a filtration system, the circulation pump and the exchanger will not become fouled.

It is advisable to ensure the water analysis before installing the system. If the potable water consists of high amounts of hardness, then there are certain treatments available for the hardness elimination. Water softener systems are effective at removing the ions that cause the water to increase in hardness. Usually, these ions tend to be magnesium, calcium, and iron ions that are targeted and removed. Ion exchange resins provide a similar function by replacing these hardness causing ions with non-hardness ions, such as sodium ions.

Fig. 6 shows the principle of PWC compressor cooling using an outdoor air conditioning unit, an exchanger and a storage tank [8]. PWC which is chemically treated to 


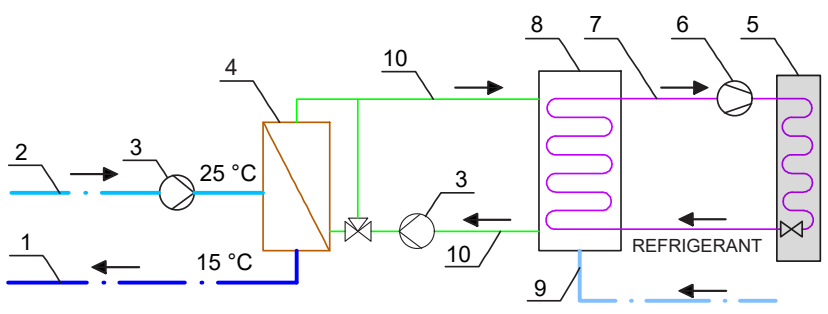

Fig. 6 Scheme of PWC compressor cooling with air conditioning unit, exchanger and storage tank (author); 1 - PWC pipe, 2 - PWC-C pipe, 3 - circulation pump, 4 - exchanger, 5 - outdoor air conditioning unit, 6 - compressor, 7 - primary cooling circuit (refrigerant), 8 - process water storage tank, 9 - process water supply to the storage tank, 10 - process water circuit

have a better ability to keep cool is supplied into the water storage tank. To the water storage tank is also distributed the refrigerant, in the separated cooling circuit, in order to cool the chemically treated PWC. The chemically treated PWC in the storage tank is cooled and is supplied in a closed circuit to the heat exchanger. On the opposite side of the exchanger the PWC from the circulation system is supplied in order to be cooled and to be distributed to the individual water consumption points with the appropriate quality. By this stage of the process, there are usually additions of chemicals such as bicarbonates which hinders acidity from occurring, and other inhibitors to avoid the build-up of scale deposits. Fortunately, pre-treatment can decrease the amount of chemicals required during this stage, which is preferred since much of these chemicals are costly.

The type of a compressor cooling is a usage of a heat pump. We distinguish active and passive heat pump cooling. For active cooling, the heat pump compressor is used for dissipation of excess heat into the air or into the primary circuit (ground collector, borehole). Fig. 7 shows the usage of an Earth-to-Water heat pump for PWC cooling.

Using a passive heat pump cooling, coldness from the ground (primary circuit) is transferred via the water exchanger to the secondary circuit only using circulating pumps, the heat pump compressor is not running.

\subsection{Solar cooling of cold water}

The other possibility of PWC cooling is solar cooling. Solar cooling systems are divided into:

- thermally controlled solar cooling systems,

- electrically controlled solar cooling systems.

In a thermally controlled solar cooling system, the thermal energy obtained from the solar collectors is used to drive the cooling system. This system consists of a

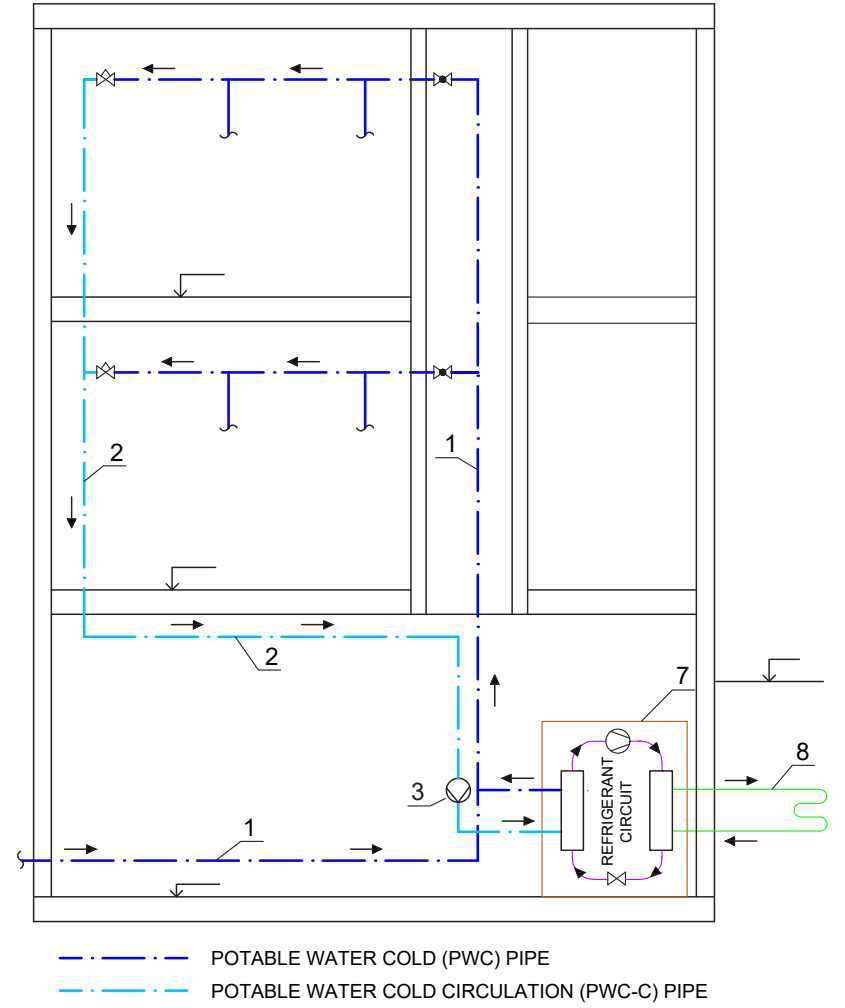

Fig. 7 Scheme of the PWC cooling using a heat pump (author); 1 - PWC pipe, 2 - PWC-C pipe, 3 - circulation pump, 4 - exchanger, 5 - air conditioning unit, 6 - refrigerant, 7 - Earth-Water heat pump, 8 - ground collector

photo-thermal panels complemented by a heat-driven cooling device. The type of solar thermal cooling is absorption cooling. The principle of absorption cooling is similar to the conventional compressor cooling described above, the only difference is in the way of obtaining a higher vapor pressure of the refrigerant needed for condensation. In an absorption cooling system, the compression of the refrigerant vapor is achieved by the thermal principle using solar heat [9].

For electrically controlled solar cooling systems, we distinguish photovoltaic compressor and photovoltaic Peltier system. In a photovoltaic compressor system, photovoltaic panels produce electricity that drives the electric compressor of the refrigeration equipment.

In the photovoltaic Peltier system, a Peltier module is used. A Peltier module (Fig. 8(a)) is an electronic element that develops different temperatures at the contact surfaces of two conductors when an electric current flows - if a direct current is applied to the leaded conductors, one side begins to cool and the other to heat (Fig. 8(b)). On the cold side a PWC storage tank for cooling can be placed. Heat will be transferred to the other side, for example, 
using a cooler, which dissipates the waste heat through the fan into the room. Another possibility is the installation of a thermo-electric cooling set of the L-L type (liquid to liquid, Fig. 8(c). The upper part of the system consists of an exchanger, where circulating PWC would be supplied at the inlet and cooled PWC intended for distribution to end users would be at the outlet of the exchanger. With this type of assembly, the waste heat is dissipated by the hot water liquid in the lower heat exchanger. The advantage of Peltier cooling is the compact size of Peltier modules and the absence of the refrigerant [10].

\section{Optimized water pipeline distribution system}

The usual water distribution pipeline system inside building (Fig. 9(a)) consists of a PWC supply to the building, a storage water heater is supplied with a PWC, then the main horizontal cold and hot water pipes are placed under the ceiling of the lowest floor, and are branched into several riser pipes. Hot water is at the highest point of the hot water supply connected to the circulation circuit, which returns the unused hot water back to the water heater for reheating.

In addition to the usual design of water pipeline system, the distribution system can be realized as a spiral [12]. In the case of a spiral distribution system (Fig. 9(b)), the main horizontal cold and hot supply pipe runs through all floors, supplies all supply points, and then returns to supply the storage water heater. The hot water is connected to the circulation behind the last hot water consumption point.

Using a spiral distribution system, each time the hot water is drawn, the PWC is supplemented to the storage water heater, which ensures a sufficient water exchange in a main supply pipe when taking cold water, but also when taking the hot water. Spiral distribution ensures hygienic water exchange in the main cold and hot water supply pipes. This system is suitable in buildings with intermittent water consumption and in buildings with high demands on water hygiene (hospitals, schools, etc.) [12].

\section{Discussion}

Potable water is hygienically safe if it does not endanger health by the presence of microorganisms. Water pipes must be projected so that there is no mutual heat transfer between cold water and hot water pipes or the surrounding environment. All water pipes must be thoroughly insulated.

For buildings where water abstraction is not ensured at least once a week (schools during a vacation, irregularly occupied hotels and hospitals, sport facilities), it is recommended to design automatic water flushing unit [13].
If there is a high temperature of cold water at the entrance to the building, it is advisable to design a system of PWC circulation and cooling system and distribute drinking water of sufficient quality to the end users. In the paper the possibilities of cooling PWC was designed regarding the use of energy renewable sources - heat pumps and solar cooling.

For summary, the comparison of individual technical solutions is given below:

1. Classic plumbing installation (Fig. 9(a)):

- Benefits:

- established system

- Negatives:

- to ensure the required PWC exchange in the pipeline, it is necessary to design a flushing system

- the need of installation of a balancing valve in the case of PWH-circulation

2. Potable water cold circulation with cooling (Fig. 3): - Benefits:

- the required exchange of potable water cold in the pipeline is ensured

- no flushing system required, PWC is not discharged into the sewerage without further use

- the possibility to regulation of potable water cold temperature $<20^{\circ} \mathrm{C}$

- Negatives:

- in existing systems in order to provide PWC cooling and circulation, there is the need to install another piping system

- investment in the cooling system

- the need for electricity to drive the cooling system

- the need of installation of a balancing valve in the case of PWC-circulation

3. Spiral plumbing installation system_(Fig. 9(b)):

- Benefits:

- the required exchange of potable water cold in the pipeline is ensured

- in comparison with a classical system, there is a lower water pipe consumption 


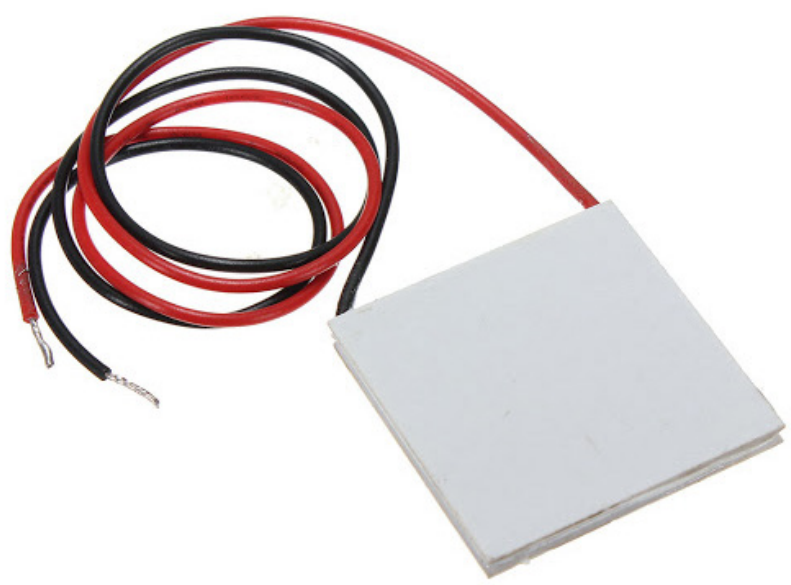

(a)

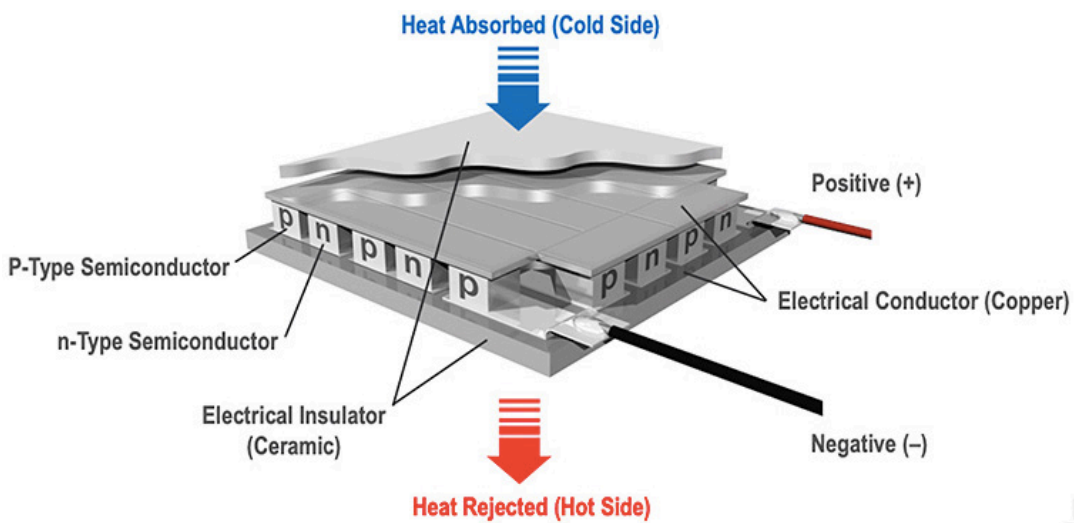

(b)

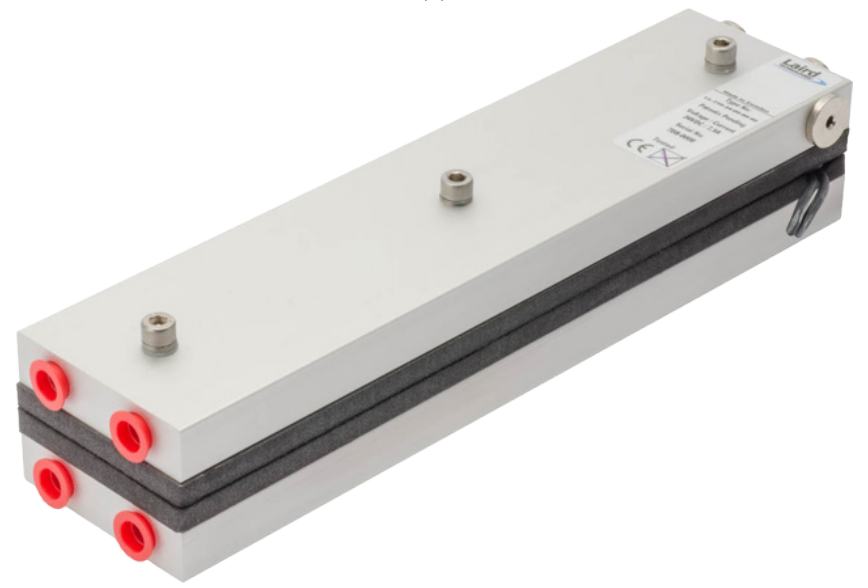

(c)

Fig. 8 Peltier module for cooling purposes [10, 11]; (a) view on Peltier module; (b) principle of operation; (c) thermo-electric cooling set of the L-L type (liquid to liquid)

- there is no need of PWH a PWC circulation, no need of installation of balancing valves and no need of electricity

- hydraulic stability of the system

- reduced costs by about $15 \%$ [12]

\section{Conclusion}

In buildings we observe a trend of decreasing water consumption, as a result of which the water flows at a slower speed and the water exchange is not sufficient. The high temperature of PWC in the water supply system at the entrance to the building in combination with insufficient 


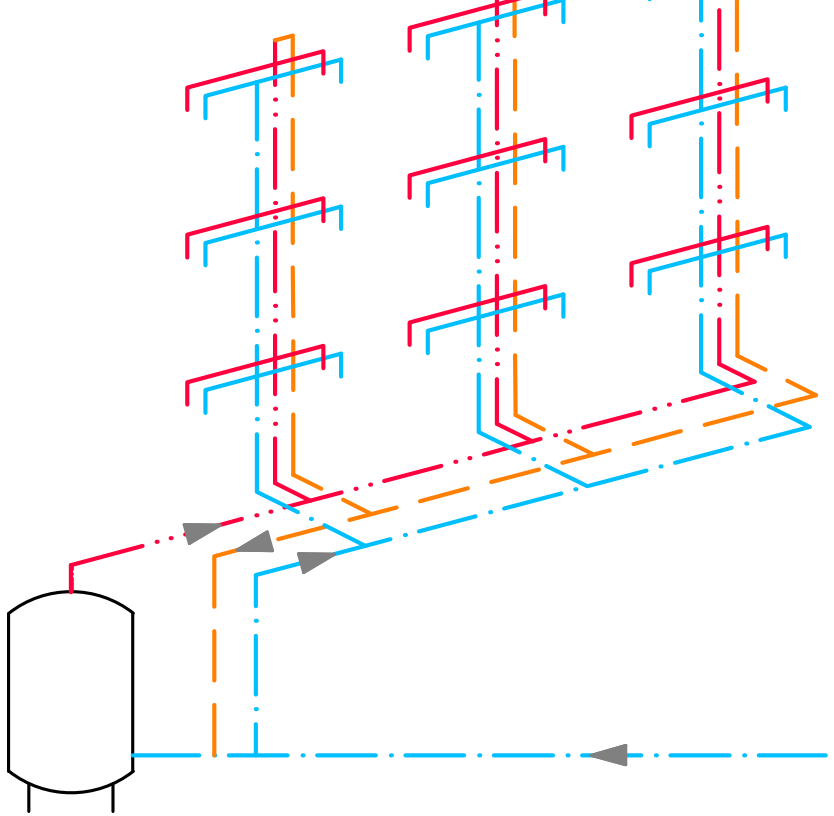

(a)

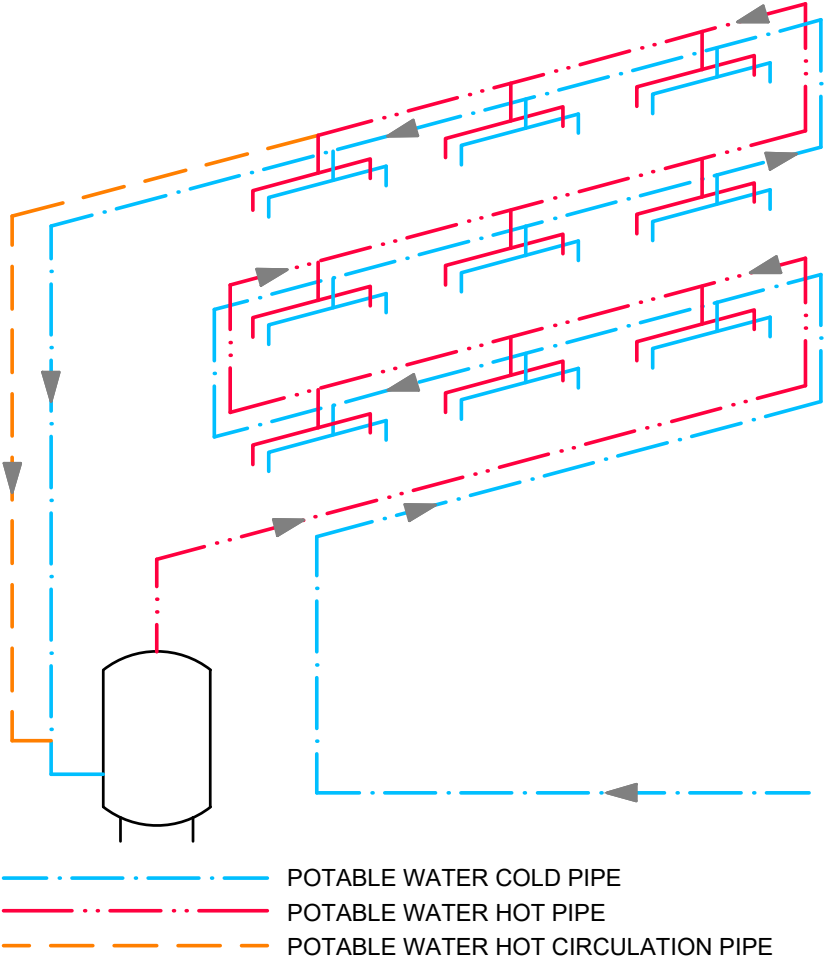

(b)

Fig. 9 Comparison of the usual and the spiral water pipeline system [12, author]; (a) classic plumbing installation, (b) spiral plumbing installation system

thermal insulation of water pipes and the lower flow of cold water causes the limit values of the PWC temperature are exceeded. As the temperature of cold water increases, the risk of microbiological contamination of potable water is also increasing [14, 15]. The system of PWC-C with its cooling is not widespread, but it would solve all problems associated with insufficient water exchange and

\section{References}

[1] European Committee for Standardization "BS EN 806-2:2005 Specification for installations inside buildings conveying water for human consumption. Part 2: Design", BSI British Standard, London, UK, 2005.

[2] Slovak Office of Standards, Metrology and Testing "TNI CEN/ TR 16355 Preventívne opatrenia proti rozmnožovaniu baktérie Legionella vo vodovodných potrubiach na pitnú vodu vnútri budov" (Recommendations for prevention of Legionella growth in installations inside buildings conveying water for human consumption), Slovak Office of Standards, Metrology and Testing, Bratislava, Slovakia, 2013. (in Slovak)

[3] Ministry of Health of the Slovak Republic "SR - 247/2017 Vyhláška, ktorou sa ustanovujú podrobnosti o kvalite pitnej vody, kontrole kvality pitnej vody, programe monitorovania a manažmente rizík pri zásobovaní pitnou vodou" (Decree laying down details on drinking water quality, drinking water quality control, monitoring and risk management of drinking water supply), Ministry of Health of the Slovak Republic, Bratislava, Slovakia, 2017. (in Slovak) high PWC temperature of. Several renewable sources can be used to cool PWC inside buildings.

\section{Acknowledgement}

This work was supported by Slovak Research and Development Agency and the Ministry of Education, Science, Research and Sport of the Slovak Republic through the grant KEGA 005STU-4/2021 and VEGA 1/0303/21.

[4] Krafčík, M. "Prietoky a spotreba vody v bytových domoch a využitie stratifikácie pri príprave teplej vody" (Water Flows and Water Consumption in Apartment Buildings and Usage of Stratifical Domestic Hot Water Preparation), PhD thesis, Slovak University of Technology in Bratislava, 2019. (in Slovak)

[5] Deutsches Institut Fur Normung "DIN 1988-200 Technische Regeln für Trinkwasser-Installationen - Teil 200: Installation Typ A (geschlossenes System) - Planung, Bauteile, Apparate, Werkstoffe; Technische Regel des DVGW" (Codes of practice for drinking water installations - Part 200: Installation Type A (closed system) - Planning, components, apparatus, materials; DVGW code of practice), German Institute for Standardisation, Berlin, Germany, 2012. (in German)

[6] Geberit International Sales AG "Drinking water hygiene", [online] Available at: www.international.geberit.com/know-how/drinking-water-hygiene [Accessed: 01 February 2021] 
[7] Heinecke, O. "Kaltwasser-Zirkulation mit Kühlung" (Cold water circulation with cooling), In: Forum Wasserhygiene Kongress, Das trinkwasser buch, Wien, Austria, 2019, pp. 44-53. (in German)

[8] Gebr. Kemper GmbH + Co. KG "Cold water circulation using KHS CoolFlow", [online] Available at: https://www.kemper-olpe. de/oc/business-units/building-technology/product-information/ khs-drinking-water-hygiene/cold-water-circulation-khs-coolflow [Accessed: 01 February 2021]

[9] Michaličková, S. "Solárne chladenie $\mathrm{v}$ budovách $\mathrm{s}$ využitím slnečnej energie" (Solar cooling in buildings), Časopis ASB, [online] 15 July 2013, 2013. Available at: https://www.asb.sk/stavebnictvo/ technicke-zariadenia-budov/fotovoltaika/solarne-chladenie-v-budovach-s-vyuzitim-slnecnej-energie [Accessed: 01 February 2021] (in Slovak)

[10] Murgaš, M. "Konštrukcia termoelektrického chladiaceho zariadenia" (Thermoelectic cooler construction), BA thesis, Brno University of Technology, 2015. (in Czech)

[11] Laird Thermal Systems GmbH "Thermoelectric Handbook - Product Information, Assembly Information, Performance, Properties", [online] Available at: https://www.lairdthermal.com/ index.php/thermal-technical-library/handbooks/thermoelectric-handbook [Accessed: 01 February 2021]
[12] Pospíchal, Z., Žabička, Z. "Pipe spiral distribution for domestic plumbing installations for fresh water", Brno, Czech Republic, PUV 2012-27011, 2012.

[13] Oventrop GmbH \& Co. KG "Aquanova-System: Distribution and hygiene of potable water", [online] Available at: https://www.oventrop.com/en-IL/productssystems/landingpages/aquanovasystem/ [Accessed: 01 May 2021]

[14] Káposztásová, D., Vranayová, Z., Purcz, P. "Water Distribution System in Building and Its Microbiological Contamination Minimization", In: Negm A., Zeleňáková M. (eds.) Water Resources in Slovakia: Part II. Climate Change, Drought and Floods, Springer International Publishing, Cham, Switzerland, 2019, pp. 251-267. https://doi.org/10.1007/698_2018_312

[15] Eördöghné, M., Takács, J. "Analýza výskytu legionel v sústavách teplej vody a opatrenia proti nim prostriedkami projektovania" (Analysis of the occurrence of bacteria Legionella in hot water systems and measures against them by means of project design), In: SANHYGA 2017, Pieštany, Slovakia, 2017, pp. 53-56. (in Slovak) 